\title{
Between West and East: A Social History of Business Journalism in Cold War Finland
}

\author{
Antti Ainamo \\ Helsinki School of Economics, Finland \\ Janne Tienari \\ Lappenranta University of Tehnology, Finland \\ Eero Vaara \\ Swedish School of Economics, Finland \\ Ecole de Management de Lyon, France
}




\begin{abstract}
The Cold War era was characterized by ideological struggles that had a major impact on economic decision-making, and also on management practice. To date, however, these ideological struggles have received little attention from management and organizational scholars. To partially fill this research gap, we focus on the role of the media in these ideological struggles. Our starting point is that the media both reflect more general societal debates but also act as an agency promoting specific kinds of ideas and ideologies. In this sense, the media exercise significant power in society; this influece, however, is often subtle and easily dismissed in historical analyses focusing on political and corporate decision-making. In this article, we focus on the role of business journalism in the ideological struggles of the Cold War era. Our case in point is Finland, which is arguably a particularly interesting example due to its geopolitical position between East and West. Our approach is socio-historical: we focus on the emergence and development of business journalism in the context of the specific struggles in the Finnish political and economic fields. Our analysis shows how the business journalists struggled between nationalist, pro-Soviet and pro-West political forces, but gradually developed into an increasingly influential force promoting neo-liberal ideology.
\end{abstract}

Keywords: business histiory, business press, ideology, journalism, management history, media.

\title{
Introduction
}

The end of the Second World War set the stage for the military, economic, and ideological polarization of Europe, and a period that has been called the Cold War. This period marked an Americanization of Western Europe while Central and Eastern 
Europe, in turn, fell behind the Iron Curtain, influenced and dominated by the Soviet Union. However, the polarization was never complete. Due to their peculiar geopolitical position, some countries were left to straddle the market economies of Western Europe and the command economies of Eastern Europe. In these countries, the Cold War era was characterized by ideological struggles that had a major impact on economic decision-making, and also on management practice. To date, however, these ideological struggles have received little attention from management and organizational scholars. In particular, we seem to know little of the impact of these ideological struggles on the promotion and legitimation of specific kinds ideas and practices in business organizations.

To partially fill this research gap, we focus on the role of the media in these ideological struggles. Our starting point is that the media both reflect more general societal debates but also act as an agency promoting specific kinds of ideas and ideologies (e.g. Fiske, 1989; van Dijk, 1990; Fairclough, 1995; Bourdieu, 1998; Luhmann, 2000). In this sense, the media exercise significant power in society; this influece, however, is often subtle and easily dismissed in historical analyses focusing on political and corporate decision-making. For business and management, business journalism is a particularly interesting part of the media (e.g. Parsons, 1989; Read, 1992). Organization and management scholars have started to pay increasing attention to this profession, which has promoted and legitimated specific kinds of ideas and practices in business organizations and society at large (e.g. Mazza \& Strandgaard Pedersen, 2004; Kjaer \& Langer, 2005). However, we have so far lacked sociohistorical analyses focusing on the ideological aspects of the development and role of this profession. 
In this article, we focus on the role of business journalism in the ideological struggles of the Cold War era. Our case in point is Finland, which is arguably a particularly interesting example due to its geo-political position between East and West. Our approach is socio-historical: we focus on the emergence and development of business journalism in the context of the specific struggles in the Finnish political and economic fields. In this analysis, we draw on extensive historical material, including interviews of business journalists and key corporate decision-makers, published reports and analyses of the media in Cold War Finland, and selections of media material of various genres. In our analysis, we aim in particular at shedding more light on how this emerging profession was shaped by the ideological struggles and how it promoted specific kinds of ideas, practices and values throughout 1945-95.

Our analysis shows how the business journalists struggled between nationalist, proSoviet and pro-West political forces, but gradually developed into an increasingly influential force promoting neoliberal ideology. More specifically, we illustrate how the postwar reconstruction period (1945 to mid-1960s) in Finnish society and economy was characterized by a national consensus on economic and business issues. During this period, business journalists acted primarily as individual reporters promoting specific business interests. Between the mid-1960s and early 1980s, Finnish society was politically and ideologically divided, and this was also reflected in the media. During this time, business journalists on the one hand became more independent and critical analysts but on the other represented an important pro-market economy force in Finnish society. From the early 1980s to mid-1990s, the Finnish political climate and especially the economic structure changed significantly and 
began to increasingly resemble the "old" Western European market economies. During this time, business journalism grew into a profession of increasing independence and influence. In particular, business journalists emerged as increasingly powerful protagonists of neoliberal ideology.

This article is structured as follows. After this introduction, we will explain what we mean when we look at the Cold War as an ideologial struggle. This is followed by a section examining the specific characteristics of business journalism as an agency promoting and legitimating particular kinds of ideas and ideologies. We then provide a brief summary of our empirical material and explain how we conducted our analysis. This is followed by our empirical analysis where we outline the role that the business journalists played in three time periods in Cold War Finland. Finally, we discuss the implications of this analysis and provide suggestions for future research.

\section{Cold War as ideological struggle}

Ideology is a concept that has been defined in notably different ways in different research traditions (e.g. Mannheim, 1979; Seliger, 1979; Boudon, 1986; Rosenberg, 1988; van Dijk, 1998; Chiapello, 2003). Destutt de Tracy was probably the first to propose that a "science of ideas" could be called "ideology." It was, however, Marx who brought this concept to the attention of broader audiences (Marx \& Engels, 1974). Accordingly, in the Marxist tradition, ideology has been seen as a "false consciousness," a distorted representation of reality that tends to mask the true power relationships and structures of domination in a society. It is especially the ruling class that imposes specific ideas values and ideas upon others. Gramsci later offered a new way of looking at ideology by introducing the concept of "hegemony" (Gramsci, 
1971). According to this view, hegemony works more subtly through the minds of people, for example, by constructing a consensus about a particular social order.

There is, however, another distinctive way of conceptualizing ideology that has grown out of the work by sociologists such as Durkheim (e.g. Geertz, 1973; Dumont, 1977), where the starting point is not a realistic or materialistic worldview but a constructionist epistemology. According to this "culturalist" conception, ideology refers to a shared framework of understanding that characterizes the social and discursive practices of a specific community. Ideology is here not something negative, distorted, or false, but rather something on which people base their interpretations. It is only from a distance or retrospectively that we can as observers point to some apparent distortions or biases in the people's views.

Some scholars have sought to synthesize these alternative conceptions on ideology (e.g. Laclau \& Mouffe, 1985; van Dijk, 1998; Chiapello, 2003). These attempts have been mostly built on the culturalist conception, but at the same time have tried to retain capacity for critical reflection. This is also our perspective in this study. In line with van Dijk (1998: 8), we view ideology as a "the basis of the social representations shared by members of a group." This means that ideologies serve as ways of organizing a multitude of social beliefs concerning what is true or false, good or bad, right or wrong, and so forth. Ideologies are, however, often self-serving and reflect the material and symbolic interests of a specific group. What is noteworthy is that ideologies "operate both at the overall, global level of social structure, for instance as the socially shared mental 'monitor' of social competition, conflict, struggle and 
inequality, and at the local level of situated social practices in everyday life" (van Dijk 1998: 8).

From this perspective, the Cold War era can be seen as a period of ideological struggle. What is important is that this ideological struggle involved concrete material questions but was, to a large extent, also a battle between alternative conceptions of right and wrong, legitimate and illegitimate concerning the organization of economic activity and the management of business organizations. In simple terms, the period following the Second World War was in European countries such as Finland characterized by the juxtaposition of the Western market economy and free trade ideology and the Soviet-type planning economy and socialist ideology.

On the one hand, US-type market economy and right-wing political programs became increasingly influential in Western Europe. Among other things, this meant that new kinds of management ideas and practices served as models to be adopted and spread among business and other kinds of organizations in the period immediately following the Second World War. For example, American corporate management practices gradually constituted the dominant model for most Western European countries (e.g. Servan-Schreiber, 1968; Engwall, 1992; Djelic, 1998; Kipping \& Bjarnar, 1998). Towards the end of the Cold War, the Western ideal became increasingly linked with neo-liberal ideology as put forth by politicians such as Ronald Reagan and Margaret Thatcher.

On the other hand, at the same time, socialism and communism as exemplified by the Soviet Union provided a powerful contrast to the free market economy model. This 
was obviously the case in the Eastern and Central European countries that were taken over by the Soviet Union after the Second World War. However, in the 1960s and 1970s in particular, socialist and communist ideas also gained ground among workers and intellectuals in Western Europe. Apart from sharing the underlying Marxist premises, many influential Western European actors also specifically linked the socialist model with overall social responsibility and global solidarity. Socialism - or various interpretations of it - thus provided an ideological counterforce to the free market ideology in general and Americanization in particular.

However, all this happened in the context of specific national economic and business systems. In specific settings, particular conceptions of national identity and interests shaped the struggle between pro-West and pro-Soviet models and practices. Nationalism thus played a central role in the ideological struggles (e.g. Anderson, 1983; Gellner, 1983; Hobsbawm, 1994). In practice, nationalism took different forms, depending on the specific geo- and socio-political conditions and the varying influences of particular political, economic and societal actors.

While many political and economic actors had a major role to play in these ideological struggles, we will in the following concentrate on the role of the media and specifically the business press in these battles. There are three reasons for this. First, the media provide an arena that arguably reflects the public opinion and specifically the ideological debates in society. Second, the media also exercise significant power in promoting and legitimating specific ideas and ideologies. Third, this power is often subtle and is easily overlooked in traditional historical analyses 
focusing, for example, on economic development or corporate decision-making. This makes it a particularly important object of study.

\section{Business Journalism as an Institutional Actor in the Ideological Struggles}

Various studies have shown how the mass media shape our views and values and thus contributes to the social construction of reality (e.g. Fiske, 1989; van Dijk, 1990; Fairclough, 1995; Bourdieu, 1998; Luhmann, 2000). In particular, the media may determine which issues to bring to the fore and which do not deserve specific attention (e.g. van Dijk, 1990). At the same time, the media legitimize and naturalize specific ideas and ideologies, but not others (e.g. Herman \& Chomsky, 1988; Fiske, 1989; Fairclough, 1995). All this happens in a system that has developed its own practices and professional norms (e.g. Bourdieu, 1998). These practices and norms are not, however, unproblematic. Bourdieu, for example (1998) argues that journalists reproduce "commonplaces," that is, what the audience already knows and wants to hear.

In general, media analyses have been relatively rare in organization and management literature. There are, however, notable examples. For instance, the representation of specific organizations and particular management issues has been an important topic (e.g. Chen and Meindl, 1991). Others have expanded on this approach and examined how specific representations in the popular culture, as reflected in the media, help us to understand particular aspects of organizations and management (e.g. CzarniawskaJoerges \& Guillet de Monthoux, 1994; Hassard and Holliday, 1998). Media have also served as a context for institutional analyses examining how specific ideologies such 
as nationalism impact media organizations and their strategic choices (e.g. Dacin, 1997).

Most importantly for our analysis, recent studies have also linked media with the spread and promotion of specific management ideas and practices (e.g. Mazza \& Alvarez, 2000; Sahlin-Anderson \& Engwall, 2003; Engwall \& Kipping, 2004). For example, Kipping and Engwall (2002) outline a symbiotic system that they term the global management knowledge industry. This consists of the interrelated elements of management practice, consultancies, media companies, and academic institutions. In this model, particular ideas and ideologies can be exported, transmitted and imported wholesale or piece by piece by media companies and their partners in the process of institutionalization of knowledge. At a more micro-level, other scholars have then examined specific cases such as mergers and acquisitions in detail and pointed to the discursive practices through which the media legitimate and naturalize specific phenomena (e.g. Hellgren et al., 2002; Vaara \& Tienari, 2002). Interestingly, this usually involves the juxtaposition of various kinds of discourses and ideologies such as nationalism and global capitalism (e.g. Tienari et al., 2003).

While there are many types of media that undoubtedly play an important in these processes, we will in the following focus on business journalism. Following the tradition in media studies, we view business journalism as a distinctive field comprising specific newspapers and magazines dealing with economic, business or management issues. Business journalism is also a specific genre within news and reporting, and it is becoming an increasingly distinctive profession with its own specific practices and norms. Having said this, it is important to note that the 
boundaries between business journalism and other forms of journalism are not fixed but somewhat arbitrary.

On the whole, business journalism has received relatively little explicit research attention until very recently (Slaatta, 2003; Mazza \& Strandgaard Pedersen, 2004; Kjaer \& Langer 2005). However, for example, Slaatta (2003) has pointed to the increasingly important role of business journalism in the media field and elaborated on its special role in our contemporary mediatized and commercialized society. Kjaer and Langer (2005) have in turn argued that business journalism has become more autonomous (moving from simple reporting of specific news to more elaborate and broader discussions of particular issues judged on the basis of journalistic relevance), that business news have become more negotiated in content (moving from single sources to more complex discussions where multiple actors are involved and where the journalists themselves also play a big role), and that business news have become boundary spanning over time (expanding to other areas). While these studies have greatly advanced our knowledge of the special role of business journalists in contemporary society, it should be noted that these analyses have mostly been based on methods such as content and discourse analysis. In fact, we lack socio-historical analyses of the development of this profession and the influence that it has had in particular societal and economic contexts. In particular, we know little of how various ideological influences have shaped the development of this profession and its practices and about the role of business journalists as protagonists of particular ideas and ideologies in specific historical contexts. 


\section{Methodology}

In this study, we adopt a socio-historial approach to the role of the business press in Cold War Finland. Our analysis is based on three sources of empirical data: interviews with business journalists and key corporate decision-makers, published reports and analyses of the media in Cold War Finland, and selections of media material of various genres. First, Antti Mikkonen, a well-known Finnish business journalist, had conducted 153 interviews of journalists and key corporate decisionmakers in 1996-1998. He made these interviews to document the development of Finnish business journalism from the Second World War to the mid-1990s, and later wrote a popular book on this topic (Mikkonen, 1998). We obtained full access to these interviews as well as other material that he had gathered, which proved to be an invaluable source for our analysis.

The interviewees include most of the key figures in Finnish business journalism, both already retired journalists and those who were active in the mid-1990s. The interviews also comprise a number of discussions with some of the key corporate decisionmakers in Finnish business organizations. Most interviewees were male, and they were typically over 50 years old. The interviews focused on topics such as the development of the journalistic practices, the emergence and development of specific genres within business journalism, the professionalization of the business press, its changing role in the Finnish media, and the relationship between business journalists and the political and management elite. Usually, the interviews centered on specific topics such as breaking news or scoops made by journalists. All interviews were fully or partially transcribed. The quotations offered in the following sections are our translations of Finnish to English. Although this material was extremely rich, its use 
was not methodologically unproblematic because we had not ourselves conducted the interviews and at times lacked contextual knowledge in specific issues such as scoops. However, Mikkonen himself helped us to interpret the material, and we also made additional interviews with current business journalists to complement the picture.

Second, we gathered and examined published reports and analyses of the media in Cold War Finland. This included studies on the historical development of the Finnish media (Jauri, 1948; Vesikansa, 1997; Klemola, 2001; Tommila \& Salokangas, 1998; Lindén, 2003), concentration of ownership and control of the Finnish media sector (Jyrkiäinen, 1994, Jyrkiäinen \& Sauri, 1997), and the coevolution of the Finnish and Swedish language press (Dacin, 1997). We also examined biographies of key individuals within the history of Finnish broadsheet newspapers (Zetterberg, 2001). In addition, we examined various articles on business journalism in SanomalehtimiesJournalisten, the professional journal of Finnish journalists.

Third, we also studied the actual media texts that had appeared in the leading outlets during the Cold War. We focused on the leading broadsheet papers (Helsingin Sanomat and Uusi Suomi) and the leading business daily (Kauppalehti) and leading business weekly (Talouselämä) that were the central outlets in the Finnish business press during the Cold War period. A summary of the history of these outlets is provided in Table 1. Note that this choice unavoidably meant that we paid less attention to specific types of economic journalism found only in the political press or local press. Neither did we examine the Swedish-speaking press in Finland. Rather than conducting a systematic content or genre analysis, we searched for, identified 
and examined overall patterns as well as focused on specific examples to map out

some of the key issues discussed and the genres used.

Table 1: Major Outlets of Business Journalism in Finland

\begin{tabular}{|c|c|}
\hline Outlet & History and characteristics \\
\hline $\begin{array}{l}\text { Uusi Suomi } \\
\text { (1847) }\end{array}$ & $\begin{array}{l}\text { In } 1847 \text {, the first major daily newspaper in the Finnish language was } \\
\text { established. Suometar ('Maiden of Finland') was the product of a cohort of } \\
\text { Finns that was overtly nationalistic. Russian censorship authorities forced the } \\
\text { publishers to change the newspaper's name. In 1869, it became Uusi Suometar } \\
\text { ('New Maiden of Finland') and in 1919, Uusi Suomi ('New Finland'), which } \\
\text { remained closely linked with the Conservative Party in Finland. In 1958, Uusi } \\
\text { Suomi acquired Kauppalehti, the business daily (see below). In the 1960s, the } \\
\text { financial performance of Uusi Suomi began to rapidly deteriorate although } \\
\text { Kauppalehti's profits helped to cover Uusi Suomi's losses. In the 1980s, Uusi } \\
\text { Suomi was acquired by Aamulehti (see below). In 1991, Aamulehti gave up on } \\
\text { Uusi Suomi, which was then closed. }\end{array}$ \\
\hline $\begin{array}{l}\text { Aamulehti } \\
\text { (1881) }\end{array}$ & $\begin{array}{l}\text { In 1881, Aamulehti was established in the industrial city of Tampere by another } \\
\text { cohort of nationalistic Finns. Since the early 1900s, it has remained closely } \\
\text { linked with the Conservative Party in Finland. Aamulehti Group merged in } \\
1998 \text { with MTV3, the leading commercial TV in Finland, to create Alma } \\
\text { Media. Apart from Aamulehti, Alma Media publishes Iltalehti, the tabloid, and } \\
\text { Kauppalehti. }\end{array}$ \\
\hline $\begin{array}{l}\text { Helsingin } \\
\text { Sanomat } \\
(\mathbf{1 8 8 9})\end{array}$ & $\begin{array}{l}\text { In 1889, Päivälehti was established by yet another cohort of nationalists. The } \\
\text { founders consisted of Finnish-speaking entrepreneurs and politicians. Russian } \\
\text { authorities closed the paper down in 1903, but it was re-established as Helsingin } \\
\text { Sanomat ('Helsinki News') in 1904. In the 1930s, Helsingin Sanomat began to } \\
\text { reinvent itself from its origins in the Finnish nationalist movement into an } \\
\text { independent and neutral outlet. It is considered liberally rightwing. Today, } \\
\text { Helsingin Sanomat has the largest absolute daily subscription rate of printed } \\
\text { media outlets in the Nordic countries. SanomaWSOY, a media corporation } \\
\text { grown around Helsingin Sanomat, remains controlled by the descendants of } \\
\text { Eero Erkko, the founder of Päivälehti. Among other papers, it publishes the } \\
\text { largest Finnish tabloid, Ilta-Sanomat. SanomaWSOY has internationalized from } \\
\text { the 1970s onwards. }\end{array}$ \\
\hline $\begin{array}{l}\text { Kauppalehti } \\
\text { (1898) }\end{array}$ & $\begin{array}{l}\text { In 1898, the Finnish Businessmen's Association established Kauppalehti ('The } \\
\text { Commerce Journal'), a newspaper specializing in issues of economy and } \\
\text { business. Kauppalehti has remained in a dominant position ever since. Since } \\
\text { 1919, it has been published five (or at times six) times a week. }\end{array}$ \\
\hline $\begin{array}{l}\text { Talouselämä } \\
\text { (1937) }\end{array}$ & $\begin{array}{l}\text { In 1937, a group of Finnish businessmen dissatisfied with Helsingin Sanomat's } \\
\text { economic-news coverage established Talouselämä ('Economic Life'). Printed in } \\
\text { magazine format in Finnish, Talouselämä emerged as the largest business } \\
\text { weekly in Finland. Challengers to Talouselämä's dominance as the main weekly } \\
\text { business magazine in Finland have appeared since the 1980s in particular. } \\
\text { Talouselämä has managed to maintain its dominant position. }\end{array}$ \\
\hline
\end{tabular}


All this provided extensive material for the description and analysis of the role of the business journalists in Cold War Finland. The use of multiple sources of data also led to data triangulation, which was particularly important in the case of interpreting the interviews. In our analysis, we identified three time periods characterized by specific political and economic conditions and particular features and developments in business journalism: the reconstruction period (1945 to the mid-1960s), the period of balancing between East and West (from the mid-1960s to the early 1980s) and the period leading to the end of the Cold War and Finland joining the European Union (from the early 1980s to the mid-1990s). The main characteristics of business journalism are summarized in Table 2 below. In the following, we will provide a condensed historical account of how the Finnish business journalism reflected the overall ideological battles in Finnish society and the role that the business journalists played in these ideological struggles. We will, however, start with a short history of the overall development of Finnish society and economy during the Cold War period. 
Table 2: Characteristics of Business Journalism during the Cold War Period in Finland

\begin{tabular}{|c|c|c|c|}
\hline & $\begin{array}{l}\text { Reconstruction period } \\
\text { (1945 to mid-1960s) }\end{array}$ & $\begin{array}{l}\text { Balancing between West and East } \\
\text { (mid-1960s to early 1980s) }\end{array}$ & $\begin{array}{l}\text { Towards the end of the Cold War } \\
\text { (early 1980s to mid-1990s) }\end{array}$ \\
\hline$\underline{\text { Issues in public debate }}$ & $\begin{array}{l}\text { Investments } \\
\text { Sales contracts }\end{array}$ & $\begin{array}{l}\text { Investments } \\
\text { Sales contracts (especially Soviet trade) } \\
\text { Financial results }\end{array}$ & $\begin{array}{l}\text { Investments } \\
\text { Financial results } \\
\text { Stock market development } \\
\text { Internationalization } \\
\text { Industrial restructuring (e.g. mergers and acquistions, downsizing, } \\
\text { shutdowns) }\end{array}$ \\
\hline$\underline{\text { Genres }}$ & $\begin{array}{l}\text { Classical economic news } \\
\text { Simple forms of business news }\end{array}$ & $\begin{array}{l}\text { Economic news } \\
\text { Various forms of business news } \\
\text { New kinds of financial analysis } \\
\text { New kinds of reportage and commentary } \\
\text { (including investigative journalism) }\end{array}$ & $\begin{array}{l}\text { All kinds of economic and business news } \\
\text { Various kinds of financial analyses } \\
\text { Various kinds of reportage and commentaries (including influential columns, } \\
\text { scoops and new kinds of investigative journalism) } \\
\text { Personal portraits and other mixed genres }\end{array}$ \\
\hline$\underline{\text { Relationship with political elite }}$ & "Old boys network" & $\begin{array}{l}\text { Tensions with the pro-Soviet elite (e.g. } \\
\text { blacklisting of Kauppalehti) } \\
\text { Alignment with the conservatives }\end{array}$ & $\begin{array}{l}\text { Mostly ideological alignment } \\
\text { Promotion of neo-liberal ideals } \\
\text { New kind of criticism }\end{array}$ \\
\hline $\begin{array}{l}\text { Relationship with corporate } \\
\text { management }\end{array}$ & "Old boys network" (implying e.g. self-censorship) & $\begin{array}{l}\text { Increasing distance } \\
\text { Specific problems caused by reporting on } \\
\text { Soviet trade } \\
\text { Some leftist voices creating specific } \\
\text { conflicts } \\
\begin{array}{l}\text { Promotion of Western models and } \\
\text { practices }\end{array}\end{array}$ & $\begin{array}{l}\text { Mostly ideological alignment (“lap dog journalism”) } \\
\text { Promotion of western models and practices } \\
\text { New kind of criticism (e.g. investigative journalism) }\end{array}$ \\
\hline Role in the media & Marginal role & $\begin{array}{l}\text { Increasing recognition } \\
\text { Promotion of market economy }\end{array}$ & $\begin{array}{l}\text { Increasingly influence (shown e.g. in space and recognition) } \\
\text { Neo-liberal voice }\end{array}$ \\
\hline Overall role in ideological struggles & Promotion of business interests & Promotion of the western model & Neo-liberal protagonists \\
\hline
\end{tabular}




\section{Cold War Finland: A Short Overview}

Finland was part of the Kingdom of Sweden for abopt 800 years. Finland adopted its judicial system, governmental administration and basic political structure from its Western neighbour. In 1809, Sweden, however, lost Finland to Russia, and Finland became a Great Duchy of Tsarist Russia. This was the case until the Russian revolution, after which Finland declared independece in 1917. The Finnish economy has traditionally been based on the forest sector, and this was also the basis for its foreign trade well into the $20^{\text {th }}$ century. In this context, it is noteworthy that the Finn Anders Chydenius spoke for the liberalization of world trade already a few years before Adam Smith (Chydenius, 1765).

In the Second World War, Finland ended up as the only country to fight both the Soviet Union (1939-1940 and 1942-1944) and Germany (1944-1945). When the war ended, the Finnish economy was in dire need of reconstruction. Large parts of eastern Finland had been lost to the Soviet Union, which also came to demand extensive war reparations from her small neighbor. War reparations were to consist mainly of metal industry products. These demanded large investments, but formed a basis for the second leg in Finnish economy.

In 1948, Finland committed itself to a Treaty of Cooperation, Friendship and Mutual Assistance with the Soviet Union. Basically a military agreement, this treaty also became the foundation for political and economic relations between Finland and the Soviet Union (e.g. Hentilä, 1998). Under Soviet pressure, Finland refused Marshall Aid (e.g. Keylor, 2003). American observers at times considered Finland a Soviet satellite (e.g. Hawthorne, 1958). However, the picture was in fact far more 
complicated. While Finnish political elite assured Soviet leaders that it "would in no circumstances turn against them," they "would not yield to demands going beyond the legitimate -to ideological demands for instance" (Jakobson, 1987: 60).

The immediate postwar years were a period of reconstruction in Finland (e.g. Hjerppe, 1989). The resettlement of refugees from areas lost in the war to the Soviet Union and of servicemen returning from the front, as well as construction work on the transportation network and industrial plants, placed heavy demands on the nation's scarce resources. Paradoxically, the postwar period marked an exceptional period of uninterrupted economic development and growth in Finland. However, the oil crisis in 1973 rendered Finland increasingly dependent on Soviet crude oil. Metal sector products were typically used to pay for oil purchases. Trade with the Soviet Union came to account for over 20 per cent of Finland's total foreign trade.

Well into the 1980s, Finland's rates of savings and investment were high (for further information, see e.g. Kekkonen, 1952; Hjerppe, 1989; Pohjola, 1996). However, as a result of deregulation of the financial markets, the rate of real investment slowed down in the 1980s. This was accompanied by a dramatic cycle of boom and bust in the financial markets in the late 1980s and early 1990s. When the Soviet Union collapsed in 1991, Finland plunged into the deepest recession in its history as an independent nation, and only rose from its predicament in the mid-1990s. Rather than the traditional wood-processing or metal industries, new technologies around electronics and telecommunications became the central driving forces of the Finnish economy. Finland joined the European Union in the beginning of 1995, which arguably marked the end of the Cold War era in Finland. 


\section{The Reconstruction Period : Promotion of Business Interests}

Immediately after the Second World War, it was difficult for Finnish journalists to obtain information about industry and business. The main reason was that business journalism in Finland was in its infancy as a recognized profession. Taloustoimittajain Kerho or "The business journalists" club" was established in 1948 with a "mission" to act as a "pressure group." In the words of a key figure: "to develop the professional competence of business journalists, particularly with respect to the national economy" and "to free members from being mere conduits of trade statistics or financial quotes, as was the prewar practice in Finland." What began as an informal club turned into a registered professional association in 1952 .

After the Second World War, the Finnish political and managerial elite formed a particular kind of "old boys' network" to which also influential journalists belonged. At the core of this network was a tight cadre of men united by wartime experiences (e.g. Virtanen, 2001). While there were major differences in education and political orientation, many of these people shared a fundamental national interest: development and modernization of Finnish society and the economy. For the business journalists, it was thus natural to organize meetings hosted by key figures of the Finnish political and corporate elite. At these meetings and other encounters, prominent business journalists were seen as part of the network. The meetings provided the club members with what was termed "background information." On the outside, business journalists were then expected to act as voices promoting knowledge of the economy and business and particularly of the specific interests of the "industry." 
Until late 1960s, business journalism was not, however, a very developed profession nor a well-recognized genre in the Finnish media. In many ways, the journalistic practices were still unclear and ambiguous. In this respect, Finnish business journalism also seemed to lag behind other Western European countries. As a prominent business journalist put it: "everything happened in Sweden four or five years before it happened in Finland."

Characteristic of the relationship between business journalists and the managerial elite was reciprocal trust. The premise was that managers "could be certain that business secrets would not be published, at least not in the next day's papers" (Helkkula, 1988: 1). Here, it is noteworthy that the Finnish managers saw almost all financial information, except for news of major investments and major deals, as "business secrets." The fora for reciprocal interaction with managers were meetings and press conferences hosted by firms, where journalists obtained information about business events such as large investments or new sales contracts. A well-known business journalist describd these events as follows: "The principle was that someone organized a press conference or a function in the evening, and they didn't even have to ask ... out of convenience, journalists agreed that, hey, we won't write anything about this for tomorrow's papers now."

To cater for the press conferences, firms were expected to serve food and drink to journalists. It became the practice in business journalism to attend such events, get a full stomach and at times quite drunk, and then head for the office to type out the news story. The most important thing was to "be able to stick the sheets of paper together, if you were really drunk, three sheets in the right order, so you wouldn't end 
up with 1,3, and 2," as a participant put it. Another convention of business journalism was "the long, wet lunch," with alcohol and food served at the expense of the top manager acting as the host. At their best (or worst), these long lunches would go on until the early morning hours.

The criticality of the business journalists was further compromised as journalism and advertising sales were not kept apart in the close networks of cooperation. Talouselämä, the business weekly, was said to have at one time attracted "fourteen pages of ads in order to cater for fourteen pages of journalistic material." As late as 1968, it was estimated that two-thirds of firms' press releases were published more or less word-for-word in Helsingin Sanomat and Uusi Suomi, the two broadsheets (Mikkonen, 1998: 42).

As to their relationship with the politicians, Soviet trade formed a particularly sensitive area. This meant that "no-one dared to ask any "stupid questions"" related to the Soviet Union, as a seasoned journalist put it. This was not only a specific practice during this period, but also something that characterized the Finnish media throughout the Cold War period (e.g. Jakobson, 1987). For example, as late as the 1980s, journalists were expected to report everything they knew about a particular topic "except when considerations of foreign policy demanded otherwise" (e.g. Huovila, 1990). Nevertheless, until the late 1960s, the business press appeared to have some leeway, as the majority of the political elite seemed to recognize the need to support the reconstruction of the Finnish economy by educating the Finnish people in economic matters. 
In this context, Kauppalehti, the leading business daily, gradually developed into a more open advocate of the Western market economy. For example, Kauppalehti took an active role in promoting integration with the western European economies. This was the case, for instance, with the free trade agreement between Finland and the EFTA countries in 1963. However, a new breed of business journalists was beginning to appear outside Kauppalehti.

Gradually, some of the journalistic ground rules were clarified. Helsingin Sanomat, the leading broadsheet, played a major role in this process as it started to invest in business news. In 1972, the business section of Helsingin Sanomat was grown on Tuesdays to allow for longer stories on significant business events, following the model of the Swedish broadsheet Dagens Nyheter. Helsingin Sanomat also acquired exclusive Finnish rights to Dow Jones electronic economic and business news services. These rights had earlier resided with Uusi Suomi, which had used them sparingly. One of the reasons for this was that Kauppalehti, which was in Uusi Suomi ownership, was to cover economic and business news. In addition, Helsingin Sanomat declared an explicit policy of journalistic independence from the concerns of advertising sales.

\section{Balancing between West and East: Business Journalism as a Pro- Market Economy Voice}

In the latter part of the 1960s, the political atmosphere in Finland intensified. Leftist ideas gained ground, and Finnish society was governed by a pro-Soviet political elite the symbol of which was the long-term president Urho Kekkonen. The Finnish media was also a part of this new pro-Soviet consensus. Self-censorship in Soviet criticism was a particularly clear sign of Finlandisierung - a term first coined by a German 
journalist - to denote the gradual falling of a neutral country under Soviet influence. Limits were, however, also set for this self-censorship. Most notably, the organization of the 1975 Helsinki Conference on Security and Cooperation made Finland's international position "more stable and secure [and] editorial judgment as to what is or is not fit to print more relaxed" towards the end of the 1970s (Jakobson, 1987: 127).

While pro-Soviet voices also started to intensify in economic matters, the Finnish business journalists - by and large - stood out as an exception. In the Finnish public debate, the business journalists continued to promote the Western market economy model and economic integration with the West. Helsingin Sanomat, Uusi Suomi, Kauppalehti and Talouselämä arguably had a key role in explaining the need for the free trade treaty with the European Economic Community (EEC) in 1973 to the “ordinary people."

While the media in general and the leftist political press in particular took a proSoviet view on the increasing economic cooperation with the Soviet Union (e.g. Tolvanen, 1982), some business journalists had apparent problems in making sense of this issue. On the one hand, these increasingly significant deals made great news. A prominent business journalist portrayed this as "a great business for the media, too, with large Finno-Soviet deals, significant to the Finnish economy, to be covered ... gigantic trade agreements and deals ... in those times you didn't get deals worth billions of marks elsewhere ... Everyone wanted to write about them."

On the other, most business journalists increasingly saw themselves as proponents of the Western market economy model. In fact, Uusi Suomi and Kauppalehti first tried to 
resist writing as much as the others about Soviet trade for ideological reasons (Tolvanen, 1982). The result was problematic for the paper. Finnish firms doing business with the Soviet Union "blacklisted" Kauppalehti in terms of advertising to remain on favourable terms with the politicians who negotiated bilateral agreements with their Soviet counterparts and often in practice dictated terms of trade for individual companies. "With a heavy heart, this profile was gradually worked on," as a leading Kauppalehti journalist put it. This meant that Kauppalehti ran a series of articles about Finnish trade with the Eastern bloc.

Over time, a group of pro-Soviet business journalists also emerged. Their style resembled the style of the pro-Soviet political media. Typically, these journalists were more interested in overall economic issues than individual companies. A journalist with a strong right-wing conviction recalls the small but loud group of left-wing business journalists: "These bloody communists did not want to touch a company with a ten foot pole, all they wanted to write about was the national economy." In any case, some of these journalists were given a great deal of space both in the broadsheets and the radio.

While the pro-Soviet political elite took distance from and viewed business journalism in a critical light, there were other actors that supported the market economy orientation of the Finnish business press. In 1975, a group of conservative businessmen established Elinkeinoelämän valtuuskunta (EVA), a think-tank with a mission to influence Finnish journalists in the direction of the "free market," and to downplay left-wing tendencies in public debate. Helsingin Sanomat, for example, had according to them offered "too much space for different kinds of political opinions" 
(Eva memo, quoted in Sanomalehtimies-Journalisten 3.7.1978). To provide room for views promoting the market economy model and western management practices, EVA also began to subsidize Uusi Suomi, which had financial difficulties. It is noteworthy that at this time Uusi Suomi owned Kauppalehti.

In the 1970s, a new distance emerged between the business journalists and the corporate elite. This was partly due to the general fear of talking about the profits in a leftist societal atmosphere. Corporate managers were "the last people to open up" to any kind of journalist. A journalist put it as follows: "If you were doing well, you did not talk about it". Instead, managers would emphasize that they are on "a social mission, providing jobs." Another reason was that also the pro-market economy business journalists were also becoming more independent and critical towards Finnish corporations and managers than before. This was shown, for example, in new kinds of financial analyses of the companies and more throrough and sometimes critical commentaries on their strategies.

In the development of journalistic practices, the reorientation of Kauppalehti in 1977 was a major turning point. The photo-journalistic intent of the new young editor-inchief was "to achieve something, things that others had not done before." Kauppalehti created itself a flow of news independent from others in Finland, with a focus on small- and medium-sized businesses. "... to actively take part and to take stands... profiling ourselves as different from Helsingin Sanomat," as it was later explained. At the same time, Talouselämä - the leading business weekly - also began to differentiate its profile with analyses and articles on the financial results of Finnish companies. Helsingin Sanomat, from 1978 onwards, combined financial analyses with 
colorful commentary on the firms' business and corporate management "to get ordinary people interested." These and other developments also meant that the business journalists became increasingly visible agents promoting modern Western management practices in the Finnish business community.

\section{Towards the End of the Cold War: Business Journalists as Protagonists of the Neo-Liberal Ideology}

As a result of the détente of the late 1970s, Finland began to open up towards the West. In particular, the Finnish political and corporate decision-makers started to pay increasing attention on the restructuration of the Finnish economic and financial system. In this sense, the development in Finland was similar to many other Western European countries, but the change from the 1970s was more accentuated than in most other societies. The deregulation of the Finnish financial system began in 1983 (e.g. Halttunen \& Suvanto, 1988), and the established power blocs in business and industry began to crumble (e.g. Kuusterä, 1990). "Significant events started to unroll: deregulation, mergers and other major events in business," as a prominent business journalist of the old school recalled. In particular, Finnish companies started to invest in internationalization, for example, by foreign acquisitions. At the same time, foreign investors' interest in Finnish companies rose. All these developments led into unprecedented hype in Finnish economy called the "casino economy" at the end of the 1980s. Interestingly, the media also became a market for mergers and acquisitions, with small local and regional papers being consolidated into large media corporations (e.g. Jyrkiäinen, 1994; Jyrkiäinen \& Sauri, 1997; Tommila \& Salokangas, 1998).

In the increasingly pro-business environment, the business journalistic models of Kauppalehti, Talouselämä and Helsingin Sanomat attracted followers. As in most 
other Western countries, new daily, weekly and monthly publications targeted at managers began to appear (for Nordic comparisons, see Hadenius \& Weibull, 1999; Slaatta, 2003; Kjaer \& Langer, 2005). The business perspective spread from the specific business sections of broadsheet newspapers into other sections. As a result, the business press grew rapidly and its significance in the Finnish media became more pronounced. At the same time, a new generation of journalists entered the field. In contrast to the 1960 s and 1970 s, they focused on financial analyses and international (Western) business models. The Western practices were also portrayed as models to be followed. In this new journalistic style, companies not conforming to these models were heavily criticized. The new cohort of business journalists thus became a social force that promoted increasingly the Western financial market driven economic model and neo-liberal ideology. Talouselämä explained this in an article reflecting their own role: "Business journalism has in Finland been more alert than the companies in detecting the new trends. There have been fights, but what the reporters have wanted, the companies have been forced to conform to" (36/1988).

In this new casino economy, the relationship between the business journalists and the managers changed in a fundamental way. First, instead of trying to guard "business secrets," many Finnish companies now were eager to inform the press about their intentions in cases such as major acquisitions or share issues. The Finnish companies also specifically started to think in terms of investor relations, and the media became an important partner in this endeavor. Second, as a parallel development, "a choir of deep throats" emerged in Finland. Managers learned to use media for their own purposes, and business journalists learned to write scoops of dramatic events such as mergers and acquisitions. Third, for the Finnish media, a number of young bankers 
and managers emerged as heroes, whose actions were seldom questioned at the time. Finnish business journalists later regretted their simple-minded enthusiasm and lack of criticism during the late 1980s. Mikkonen, for example, saw this as "lap dog" journalism (Mikkonen, 1998) A seasoned journalist put it as follows: "Looking back at those years from 1987 to 1989 in particular, [we acted as] third rate detectives. We were just good at making the news of the day. That's sad ... but the events covered were just so damned dramatic!”

When the Soviet Union collapsed in 1991, Finland plunged into the deepest recession in its history as an independent nation. The recession was an international one, but was particularly severe in Finland due to the collapse of the Soviet trade. The drastic consequences such as stock market crash, massive unemployment, and the banking crisis triggered new kinds of reflections in the media in general and in the business press in particular. This also led to considerable self-criticism, as in the quotations above. Metsälampi, for example, argued that business journalists lived in a hubris that prevented them from seeing the problems leading to the banking crisis (Journalisti, 4.3.1993).

In particular, new kinds of genres such as investigative journalism became institutionalized parts of Finnish business journalism. Business journalists started to proactively hunt down stories following the traditions of American investigative journalism, instead of only passively waiting for news to unfold. The scoop concerning the merger of a toppling bank with its main rival in 1995 brought forward several days before the intended announcement was seen as a major event in the 
history of Finnish business journalism. In the words of one of the interviewed business journalists, this "illustrates the strength of real-time media."

The collapse of the Soviet Union also trigered a debate concerning potential membership in the European Union. The business press supported the membership strongly, and arguably business journalists had a also a major impact on the overall stands and policies of the major broadsheets. According to our interviews, the political, managerial and media elite once again formed a strong alliance for "promoting the national cause," as in the case of the EFTA (1963) or EEC (1972) agreements.

\section{Conclusion}

Despite the significance of the Cold War period, we know little of its impact on economic and business systems in specific countries. In particular, there is a paucity of knowledge concerning the ideological struggles defining what is important and legitimate for business organizations and their management. To partially bridge this gap, we have in this article examined the role of the media in the Cold War settings and specifically focused on the role of business journalism in the ideological struggles of Cold War Finland. In our analysis, we showed how this profession was both shaped by the ideological struggles and how it acted as an agent promoting specific kinds of ideas, practices and values in 1945-1995. More specifically, we illustrated how this role changed during specific periods, partly as a result of the overall changes in economic and political settings, but also as a result of the development of this profession. During the reconstruction period (1945 to the mid-1960s), Finnish business journalists acted primarily as individual reporters promoting specific 
business interests. Between the mid-1960s and the early 1980s, business journalists by and large promoted the market economy model in Finnish society, but also pro-Soviet voices could be heard among the business journalists. From the early 1980s to the mid-1990s, business journalists then began to act as increasingly powerful protagonists of neo-liberal ideology. While the Finnish case certainly has unique features, we argue that our findings also have broader significance.

In our view, this study makes contributions to three literatures. First, to our knowledge, this is the first analysis to focus on the role of the media in the ideological struggles concerning economic and business issues in the Cold War period and thus contributes to the nascent literature on organizations and management in the Cold War context. Importantly, our analysis illustrates that the Cold War period was not only a battle between Western and Eastern political influence, market or planning economy, or conservative and socialist ideologies, but a struggle the exact nature of which depended on the time period and context. As our case shows, particular interpretations of national interests played a major role in these ideological struggles, the importance of which should not be underestimated. In the Finnish case, in particular, nationalism both served as a basis for consensus and was at times used a rhetorical weapon for specific political purposes (see also Dacin, 1997).

Our analysis also shows that a more complete and nuanced picture of the Cold War era requires not only a careful analysis of the overall global political and economic changes, the decisions made by local politicians, or the actions taken by specific corporate decision-makers, but also a recognition of the role that the media - and in our case business journalists - have played in promoting and legitimating specific 
ideas and ideologies. To make it clear, we are not arguing that business journalism was the most important or the most decisive political or social force in Cold War Finland. However, we are saying that this profession came to act as an increasingly important protagonist of market economy and later neo-liberal ideals, without which the spread and adoption of specific Western ideas and practices would have most certainly been much slower and much more difficult in Finnish business organizations and society at large.

Importantly, it was the increasing professionalization of the business journalists that made this group a powerful social force not only vis-à-vis political decision-makers but also corporate managers. Depending on the context, this protagonist role could imply different kind of influence. For example, in the 1970s, business journalists were among the first to promote western style open financial reporting standards and a more critical public scrutiny of business issues to Finnish business organizations. In contrast, in the 1980s, the increasingly strong neo-liberal orientation of the business journalists led at times to "lap dog journalism" vis-à-vis the international growth and stock market operations of the Finnish companies.

Second, our analysis also adds to our understanding of the development of business journalism and hence contributes to the emerging literature on business journalism (Slaatta, 2003; Mazza \& Strandgaard Pedersen, 2004; Kjaer \& Langer, 2005). In particular, our socio-historical approach provides a new perspective to this research area characterized by content analyses and studies of specific issues. In several ways, our findings seem to complement the observations made by Slaatta (2003) and Kjaer and Langer (2005) on the increasingly influential role of the business press in 
contemporary society. However, by showing how business journalism was constrained by particular societal and political forces and characterized by specific practices, our analysis provides a more nuanced picture of the development of this profession that we have been used to see. It thus also paves the way for similar kinds of analysis in other contexts.

Third, this analysis also provides a new perspective on the discussions concerning the spread of management ideas and ideologies. While the central role of the media has been acknowledged and examined in this literature (e.g. Abrahamson, 1996; Mazza \& Alvarez, 2000; Sahlin-Andersson \& Engwall, 2003; Engwall \& Kipping, 2004; Alvarez et al., 2005), there have been few studies of the longer term socio-political influence of the business press. Our analysis of the Finnish case provides an example of how the relationships between the central institutional actors can be very intense in a small country characterized by close networks, thereby speeding up the spread of particular ideas. In addition, our analysis shows the importance of the ideological dimension, which easily passes unnoticed in analyses focusing on specific ideas or practices.

This exploratory study raises new questions for future research. First, while we see Finland as a particularly revealing case, it would be interesting to study the role of business journalism in other countries struggling between the East and the West and compare the findings. Second, while we have conducted a socio-historical study that has highlighted the emergence of specific kinds of journalistic practices, it would be meaningful to go further with a more systematic analysis of the development of particular kinds of genres and styles of reporting. This would allow us to better 
understand the discursive features charaterizing business journalism at different time periods as well their linkages with dominant ideologies. Such analysis could draw, for example, on critical discourse analysis (e.g. van Dijk 1998; Fairclough 2003). Third, to be able to focus on the processes of legitimation and naturalization, it would be interesting to focus on specific management ideas and track discussions around these in the business press. Fourth, as our analysis has shown, the journalistic practices and their ethical interpretations have varied over time. If we want to better understand the overall role of business journalists in contemporary society, it would be meaningful to focus on the evolving relationships between journalists and business leaders and to examine the ethical implications of the established journalistic practices as well as changes in them in more detail.

\section{Acknowledgements}

We wish to thank Joint Committee of Nordic Social Science Resesrch Council, Liikesivistysrahasto (Foundation for Economic Education), Marcus Wallberg research foundation, and Jenny and Antti Wihuri Foundation for their support. We are grateful for the comments received at the annual conference of the European Business History Association in Helsinki 2002, the annual, conference of the European Group for Organization Studies in Copenhagen 2003 and the workshops organized by the Nordic Business Press project. We also wish to thank John Meyer, Helena Buhr, the editors of this special issue, as well as the three anonymous rewiewers for their insightful commnents. 


\section{References}

Abrahamson, E: Management fashion. Academy of Management Review, 1996, 21, 254-285.

Alvarez, J. L., Mazza, C. and Strandgaard Pedersen, J. The role of mass media in the consumption of management knowledge. Scandinavian Journal of Management, 2005, 21, 127-132.

Anderson, B. Imagined communities: Reflections on the origin and spread of nationalism. London: Verso Editions and NLB, 1983.

Boudon, R. L'idéologie ou l'origine des idées recues. Paris: Fayard, 1986.

Bourdieu, Pierre. On television. New York: The New Press, 1998.

Chen, C. C. \& Meindl, J. R. The construction of leadership images in popular press: The case of Donald Burr and People Express. Administrative Science Quarterly, 1991, 36, 521-551.

Chiapello, E. Reconciling the two principal meanings of the notion of ideology: The example of the concept of 'Spirit of Capitalism'. European Journal of Social Theory, 2003, 6, 155171.

Chydenius, A. The national gain. 1765.

Czarniawska-Joerges, B. \& Guillet de Monthoux, P. Good novels, better management: Reading organizational realities in fiction. London: Harwood Academic Publishers, 1994.

Dacin, T. Isomorphism in context: The power and prescription of institutional norms. Academy of Management Journal, 1997, 40, 46-81.

Djelic, M.-L. Exporting the American model. Oxford: Oxford University Press, 1998.

Dumont, L. Homo Aeqalis: Genèse et épanouissement de lídéologie économique. Paris: Gallimard, 1977.

Engwall, L. Mercury meets Minerva: Business studies and higher education: The Swedish case. Oxford: Pergamon Press, 1992.

Engwall, L \& Kipping, M. Introduction: The dissemination of management knowledge, Management Learning, 2004, 35, 243-253.

Fairclough, N. Media discourse. London: Edward Arnold, 1995.

Fairclough, N. Analysing discourse: Textual analysis for social research. London: Longman, 2003.

Fiske, J. Reading the popular. London: Unwin Hyman, 1989.

Geertz, C. The Interpretation of Cultures. New York: Basic Books, 1973.

Gellner, E. 1983. Nations and nationalism. Oxford: Blackwell, 1983.

Gramsci, A. Selections from the prison notebooks. London: Lawrence and Wishart, 1971.

Hadenius, S. \& Weibull, L. The Swedish newspaper system in the late 1990s. Tradition and transition. Nordicum Review, 1999, 20, 129-152.

Halttunen, H. and Suvanto, A. Rahoitusinnovaatiot ja Suomen rahamarkkinat. In Raha, inflaatio ja talouspolitiikka. Eds. S. Honkapohja \& A. Suvanto. Helsinki: Valtion painatuskeskus, 1988.

Hassard, J. \& Holliday, R. Organization-representation: Work and organizations in popular culture. London: Sage, 1998.

Hawthorne, D. The ordeal of the captive nations. Garden City, NY: Doubleday, 1958.

Helkkula, E. 40 vuotta Taloustoimittajain Kerhoa. Helsinki: Taloustoimittajain Kerho, 1988.

Hellgren, Bo, Löwsted, J., Puttonen, L., Tienari, J., Vaara, E. \& Werr, A. How issues become (re)constructed in the media: Discursive practices in the AstraZeneca merger. British Journal of Management, 2003, 13, 123-140.

Hentilä, S. Living next door to the bear: How did Finland survive the Cold War? Historiallinen aikakauskirja / Historical Journal, 1998, 96, 129-136.

Herman, E. \& Chomsky, N. Manufacturing consent. New York: Pantheon Books, 1988.

Hjerppe, R. The Finnish economy 1860-1985: Growth and structural Change. Helsinki: Valtion painatuskeskus, 1989.

Hobsbawm, E. Age of Extremes: The Short Twentieth Century 1914-1991. UK: Michael Joseph, 1994.

Huovila, T. Roskapankkijuttu syksyllä 1993. Tiedotustutkimus, 1/1994, 47-56. 
Jakobson, M. Finland: Myth and reality. Helsinki: Otava, 1987.

Jauri, E. Kauppalehti 1898-1948. Helsinki: Kauppalehti, 1948.

Jyrkiäinen, J. Sanomalehdistön keskittyminen - joukkoviestinnän ja erityisesti sanomalehdistön keskittymisilmiö, sen kulku ja seuraukset jälkiteollisissa yhteiskunnissa 1980-luvun lopulla. Tampere: University of Tampere, 1994.

Jyrkiäinen, J. \& Sauri, T. The mass media in Finland - Trends in development. In Media Trends 1997 in Denmark, Finland, Iceland, Norway and Sweden. Eds. U. Carlsson \& E. Harrie. Gothenburg: Nordicom, 1997.

Kekkonen, U. Onko maallamme malttia vaurastua? Helsinki: Otava, 1952.

Keylor, W. A World of nations: The international order since 1945. Oxford: Oxford University Press, 2003.

Kipping, M. \& Engwall, L. Management consulting: Emergence and dynamics of a knowledge industry. Oxford: Oxford University Press, 2002.

Kipping, M. \& Bjarnar, O. The Americanization of European Business: The Marshall plan and the transfer of US tanagement models. London: Routledge, 1998.

Kjaer, P. \& Langer, R. Infused with news value: Management, managerial knowledge and the institutionalization of business news. Scandinavian Journal of Management, 2005, 21, 209-233.

Klemola, P. Helsingin Sanomat - sananvapauden monopoli. Helsinki: Otava, 1981.

Kuusterä, A. Taloudellisesta vallasta Suomessa: Historiaa - käsitteitä - empiriaa. TTT Katsaus, 4/1990, 31-40.

Laclau, E. \& Mouffe, C. Hegemony and socialist strategy. London: Verso, 1985.

Lindén, C.-G. Snabbhet, djup, relevans: Rapport om ekonomijournalistiken. Helsinki: Helsingfors Universitet, 2003.

Luhmann, N. The reality of the mass media. Stanford: Stanford University Press, 2000.

Mannheim, K. Ideology and utopia. London: Routledge, 1979.

Marx, K. \& Engels, F. The German ideology. London: Arthur, 1974.

Mazza, C. \& Alverez, J.-L. Haute Couture and Prêt-à-Porter. The popular press and the diffusion of management practices, Organization Studies, 2000, 21, 567-588.

Mazza, C. \& Strandgaard Pedersen, J. From press to E-media? The transformation of an organizational field, Organization Studies, 2004, 25, 875-896.

Mikkonen, M. Rahavallan rakkikoirat: Tositarinoita talousjournalismista. Porvoo: WSOY, 1998.

Parsons, W. The power of the financial press: Journalism and economic opinion in Britain and America. Aldershot: Edward Elgar, 1989.

Pohjola, M. Tehoton pääoma: Uusi näkökulma taloutemme ongelmiin. Helsinki: WSOY, 1996.

Read, D. The power of the news: The history of the Reuters. Oxford: Oxford University Press, 1992.

Rosenberg, S. J. Reason, ideology and politics. Princeton: Princeton University Press, 1988.

Sahlin-Anderson, K. \& Engwall, L. Carriers of Management Knowledge. Palo Alto: Stanford University Press, 2003.

Seliger, M. The Marxist conception of ideology: A critical essay. Cambridge: Cambridge University Press, 1979.

Servan-Schreiber, J.-J. Le défi Américain. Paris: Ed. Denoel, 1968.

Slaatta, T. Den norske medieorden: Posisjoner och privilegier. Oslo: Gyldendal Norsk Forlag, 2003.

Tienari, J., Vaara, E. \& Björkman, I. Global capitalism meets national spirit: Discourses in media texts on a cross-border acquisition. Journal of Management Inquiry, 2003, 12, 377393.

Tolvanen, O. Suomen tärkeimpien sanomalehtien suhtautuminen taloudelliseen yhteistyöhön Neuvostoliiton kanssa vuosina 1961-1971. Master's thesis, Political history, University of Helsinki, 1982.

Tommila, P. \& Salokangas, R. Sanomia kaikille: Suomen lehdistön historia. Helsinki: Edita, 1998. 
Vaara, E. \& Tienari, J. Justification, legitimization and naturalization of mergers and acquisitions: A critical discourse analysis of media texts. Organization, 2002, 9, 274-304.

Van Dijk, T. Ideology: A multidisciplinary approach. London: Sage, 1998.

Van Dijk, T. News as discourse. Lawrence Erlbaum, 1990.

Vesikansa, J. Sinivalkoiseen Suomeen: Uuden Suomen ja sen edeltäjien historia 1847-1939. Keuruu: Otava, 1997.

Virtanen, M. Fennoman perilliset: Poliittiset traditiot ja sukupolvien dynamiikka. Helsinki: SKS, 2001.

Zetterberg, S. Eero Erkko. Helsinki: Otava, 2001. 